Pak. j. sci. ind. res. Ser. B: biol. sci. 201154 (3) 117-121

\title{
Efficient Method of Choosing Potential Parents and Hybrids: Line $\times$ Tester Analysis of Spring Wheat (Triticum aestivum L.) Cultivars
}

\author{
Muhammad Jurial Baloch*, Inayat Ali Mallano, Abdul Wahid Baloch, Wajid Ali Jatoi and \\ Nasreen Fatima Veesar \\ Department of Plant Breeding and Genetics, Sindh Agriculture University, Tandojam, Pakistan
}

(received May 19, 2010; revised July 30, 2011; accepted August 17, 2011)

\begin{abstract}
The study was conducted to estimate the general combining ability (GCA) and specific combining ability (SCA) of wheat genotypes crossed in a line $\times$ tester fashion. The mean squares due to $\mathrm{F}_{1}$ hybrids, female lines, male testers/pollinators and lines $\times$ tester interaction were significant for majority of the characters studied. The significance of GCA and SCA variances thus suggested that both additive and nonadditive genes were controlling majority of the characters, yet additive genes were more prominent because variances due to GCA by and large were higher than due to SCA. Among the three female lines evaluated, Khirman displayed maximum positive GCA effects for spike length (0.08) and seeds/spike (0.67), while other female lines which showed maximum positive GCA effects were Mehran for plant height (3.05), number of tillers/plant (1.00), spikelets/spike (1.92) and seed index (3.42) and Kiran for seeds/spike (0.67) and yield/plant (1.86). From the male testers, TD-1 exhibited greater GCA effects for number of tillers/plant (2.96), spikelets/spike (0.25), seed index (0.61) and yield/plant (2.22), whereas, Marvi displayed highest positive GCA effects for plant height (2.88), spike length (0.37) and seeds/spike (6.41). The specific combining ability estimates indicated, if hybrid crop development is feasible then, crosses Mehran $\times$ TD-1 for spike length; Kiran $\times$ TD-1 for plant height and seeds/spike and Khirman $\times$ Marvi for number of tillers/plant, spikelets/spike, seed index and yield/plant may be the hybrids of choice.
\end{abstract}

Keywords: combining ability, line $\times$ tester analysis, quantitative traits, Triticum aestivum L. additive genes, non-additive genes

\section{Introduction}

Over the past three decades, increased agricultural productivity occurred largely due to the evolution of high-yielding cultivars and increased fertilizer use. However, with the introduction of semi-dwarf wheat cultivars, wheat productivity has been augmented in all the major cropping systems representing the diverse and varying agro-ecological conditions (PARC, 2006). Further advancement in the yield of wheat requires certain information regarding heterosis and combining ability of parents which is useful for the exploitation of successful hybridization programme and hybrid crop development. The nature of gene action involved in the expression of quantitative traits of economic importance has got an additional role in relying upon the breeding strategies. Thus, the fundamental issue in hybrid breeding is the choice of parents and identification of superior hybrid combinations. Earlier, it was reported as high as 141.7 and $18.9 \%$ heterosis in tillers/plant and grain yield/plant, respectively (Sedeque et al., 1991). Fida et al. (2004)

*Author for correspondence; E-mail: j.rind58@gmail.com measured positive heterotic effects as 11.61, 61.90, 30.67 and $51.89 \%$ for plant height, tillers/plant, grains/ spike and grain weight, respectively. Another study by Patwary et al. (1986), made on grain yield/plant from seven cultivars and their $42 \mathrm{~F}_{1}$ hybrids revealed that 12 crosses showed significant positive heterosis in grain yield varying from 77.15 to $160.43 \%$. As such heterosis expressed as per se hybrids is not as much reliable as the SCA of the parents (Baloch and Bhutto, 2003).

Due to its greater genetic diversification, wheat provides many opportunities for the development of new high yielding genotypes through crossing and recombination of desirable genes. Nevertheless, an understanding of the genetic factors that govern the yield components is the primary step towards any breeding endeavors. For wheat breeders, the search for desirable germplasm is a continuous process and the development of new varieties is an un-ending goal. In this context, knowing the extent of inheritance of desirable traits from parents to the offspring is of utmost importance for further improvement. 
For this purpose, the line $\times$ tester mating design was used to estimate GCA and SCA variances and their effects. Though, diallel is most commonly used mating design for estimating combining ability, yet it involves fewer and same set of parents being male and females thus gives just only one estimate of GCA whereas, line $x$ tester mating design uses different sets of males and females hence provides two independent estimates of GCA of lines and testers separately. A general combining ability is defined as an average performance of a line in a series of crosses while specific combining ability connotes those instances where certain hybrids are either better or poorer than would be expected on average performance of parents in hybrid combinations (Sprague and Tatum, 1942). Despite the fact that, a lot of research on combining ability has been carried-out by wheat breeders, yet controversy in results always remained a debate which existed either due to material used, or environment in which material was tested or the breeding methodology adopted. Rajara and Maheshwari (1996) and Dhadhal and Dobariya (2006) reported the importance of both additive and non-additive genes yet found preponderance of non-additive gene effects for grain yield/plant, plant height and spikelets/spike. Similarly, Singh and Singh (2003) studied $80 \mathrm{~F}_{1} \mathrm{~s}$ developed from 4 lines crossed with 20 testers evaluated via line $\times$ tester analysis. The estimates of variance components due to general combining ability (GCA) and specific combining ability (SCA) indicated the predominance of non-additive genes for plant height, spike length, number of spikelets/spike, grain weight /spike, 100-seed weight and yield/plant. Ribadia et al. (2007) estimated general and specific combining ability and found high proportion of non-additive genes for plant height, length of main spike, spikelets/spike, grain yield/plant and grain weight/spike. Nevertheless, contrary to these findings, Hamada et al. (2002) while working with thirty-five introduced wheat lines crossed with four local wheat cultivars as testers and produced 140 hybrids using line $\times$ tester analysis to estimate combining ability effects and gene action for plant height, spike length, number of kernels/spike, 1000-kernel weight and grain yield/plant. They found significant differences for lines, testers and lines $\times$ testers' interaction for all the traits except spike length. Their results further revealed that additive gene effects were larger than those of the non-additive ones. Similarly, Vanpariya et al. (2006) crossed 10 lines with 4 testers and found that both additive and non-additive gene actions were important, yet the ratio of GCA/SCA showed the preponderance of additive genes for plant height, length of main spike and spikelets/spike. While non-additive genes were prevailing for grain yield/plant, grains/ spike, 100-grain weight and grain yield/spike. Esmail (2007), crossed ten bread wheat lines with three testers and noted additive as well as dominance genetic components playing a role in the inheritance of plant height. The present study therefore was aimed at estimating the combining ability of bread spring wheat genotypes by line $\times$ tester analysis for quantitative traits.

\section{Materials and Methods}

The research was conducted during 2007 at the Experimental Field, Department of Plant Breeding and Genetics, Sindh Agriculture University, Tandojam, Province of Sindh, Pakistan, so as to identify good general and specific combining parents and also to determine the nature of gene action governing for different characters in spring wheat genotypes by line $\times$ tester analysis. The trial comprised of $6 \mathrm{~F}_{1}$ hybrids and their 5 parents (three lines, Khirman, Mehran-89, Kiran-95 and two testers, TD-1, Marvi). The experiment was laid-out in a Randomized Complete Block Design with three replications. The analysis of variance was carried-out according to statistical methods developed by Gomez and Gomez (1984) whereas, the general and specific combining ability variances and effects were estimated according to methods developed by Kempthorn (1957) and adopted by Singh and Choudhry (1979). The data were recorded on plant height (cm), number of tillers/ plant, spike length ( $\mathrm{cm})$, grains/spike, spikelets/spike, yield/plant (g) and seed index (1000grain weight in g). All the cultural practices were done as and when required while fertilizer and irrigations were applied according to the recommendations of wheat crop for local conditions.

\section{Results and Discussion}

The research was conducted for estimating the general combining ability (GCA) and specific combining ability (SCA) of wheat genotypes for some quantitative traits via line $\times$ tester analysis. The mean squares due to $F_{1}$ hybrids, female lines, male testers and lines $\times$ tester interactions were significant for all the characters, except GCA of line and testers for spike length and spikelets/ spike, respectively and SCA for spike length only were non-significant (Table 1). The significance of mean squares due to female and male inbreds both designate GCA variances while female $\times$ male interaction which designate SCA variances employed that additive as well 
as dominant genes were important for most of the characters studied. In respect to per se $\mathrm{F}_{1}$ hybrids' performance summarized in Table 2 indicated that cross Mehran $\times$ TD- 1 produced maximum number of tillers/plant (26.5), gave more spikelets/spike (25.0), recorded highest seed index (40.4g) and produced maximum seed yield/plant (53.6g). However, hybrid Khirman $\times$ Marvi measured tallest plants $(94.5 \mathrm{~cm})$, and gave more seeds/spike (92.5), while Kiran $\times$ Marvi, gave longer spikes $(14.8 \mathrm{~cm})$. By and large, per se hybrid performance was not reflected in general or in specific combining ability of the parents except Mehran $\times$ TD- 1 which was good as per se $\mathrm{F}_{1}$ hybrid and average general combiners as well for number of tillers/plant, spikelets/spike, seed index and yield/plant, therefore both the parents can reliably be used in hybridization and selection programme to improve majority of the characters (Table 2, Fig. 1). Similar to our findings, Vanpariya et al. (2006) found that parents in cross CPAN $1933 \times$ GW 173 was one most promising parent as it had high SCA effect and simultaneously as best per se $\mathrm{F}_{1}$ hybrid for length of main spike, spikelets/spike and number of grains/spike. However, the lowest yielder per se $\mathrm{F}_{1}$ hybrid (Khirman $\times$ Marvi) was the specific combiner (Fig. 1). These results suggested that per se $\mathrm{F}_{1}$ hybrid performance should not always be taken granted for having good SCA also. Mean squares due to GCA for both lines and testers were significant for majority of the characters (Table 1). Similar to our findings, Nazan (2008) had found significant GCA variances for grain yield/spike, plant height, spike length, spikelet number/spike, kernel number/spike,

Table 1. Mean squares from lines $\times$ testers analysis for various characters in spring wheat (Triticum aestivum L.)

\begin{tabular}{llllll}
\hline \hline Traits & $\begin{array}{l}\mathrm{F}_{1} \text { hybrids } \\
\mathrm{DF}=5\end{array}$ & $\begin{array}{l}\text { Lines (GCA) } \\
\mathrm{DF}=2\end{array}$ & $\begin{array}{l}\text { Testers (GCA) } \\
\mathrm{DF}=1\end{array}$ & $\begin{array}{l}\text { Lines } \times \text { Testers } \\
\text { (SCA) } \\
\mathrm{DF}=2\end{array}$ & $\begin{array}{l}\text { Error } \\
\mathrm{DF}=12\end{array}$ \\
\hline Plant height & $109.56^{* *}$ & $69.29^{* *}$ & $198.38^{* *}$ & $40.88^{* *}$ & 7.97 \\
Tillers/plant & $96.78^{* *}$ & $6.50^{* *}$ & $210.04^{* *}$ & $28.67^{* *}$ & 1.25 \\
Spike length & $1.78^{* *}$ & 1.17 & $3.38^{* *}$ & 0.50 & 0.33 \\
Spikelets/spike & $10.43^{* *}$ & $22.17^{* *}$ & 1.50 & $13.50^{* *}$ & 0.72 \\
Seeds/spike & $443.47^{* *}$ & $10.67^{* *}$ & $988.17^{* *}$ & $115.17^{* *}$ & 12.53 \\
Seed index & $54.60^{* *}$ & $70.21^{* *}$ & $8.88^{* *}$ & $92.50^{* *}$ & 1.85 \\
Yield/plant & $82.05^{* *}$ & $75.95^{* *}$ & $117.64^{* *}$ & $49.49^{* *}$ & 1.95 \\
\hline \hline
\end{tabular}

** = Significant at $1 \%$ probability level.

Table 2. Specific combining ability estimates and per se average performance of $\mathrm{F}_{1}$ hybrids (in parenthesis) for various characters in spring wheat (Triticum aestivum L.)

\begin{tabular}{llllllll}
\hline \hline $\mathrm{F}_{1}$ hybrids & \multicolumn{3}{l}{ Plant height } & Tillers/plant & \multicolumn{5}{l}{ Spike length } & Spikelet/spike & \multicolumn{2}{l}{ Seeds/spike } & Seed index & Yield/plant \\
\hline Khirman $\times$ TD-1 & -2.83 & -1.33 & 0.01 & -1.5 & -4.07 & 3.88 & 1.15 \\
& $(84.0)$ & $(21.3)$ & $(13.5)$ & $(20.0)$ & $(71.5)$ & $(39.5)$ & $(47.8)$ \\
Mehran $\times$ TD-1 & -5.63 & -2.08 & 0.51 & -2.25 & 5.47 & -8.40 & -2.70 \\
& $(91.8)$ & $(26.5)$ & $(13.3)$ & $(25.0)$ & $(74.3)$ & $(40.4)$ & $(53.6)$ \\
Kiran $\times$ TD-1 & 9.5 & -6.83 & -0.24 & 1.75 & 10.17 & 4.16 & -6.28 \\
& $(84.0)$ & $(22.3)$ & $(13.5)$ & $(22.0)$ & $(79.0)$ & $(32.2)$ & $(49.2)$ \\
Khirman $\times$ Marvi & -0.38 & 9.84 & -0.99 & 4.00 & -14.16 & 6.11 & 11.37 \\
& $(94.5)$ & $(18.0)$ & $(14.3)$ & $(22.5)$ & $(92.5)$ & $(30.8)$ & $(41.1)$ \\
Mehran $\times$ Marvi & -0.88 & -0.41 & 0.51 & -1.25 & 6.08 & -8.65 & -6.42 \\
& $(93.3)$ & $(16.3)$ & $(13.5)$ & $(23.0)$ & $(85.8)$ & $(39.7)$ & $(45.8)$ \\
Kiran $\times$ Marvi & -0.25 & 0.84 & 0.26 & -0.75 & -3.41 & 3.28 & 2.85 \\
& $(89.3)$ & $(18.0)$ & $(14.8)$ & $(20.0)$ & $(85.0)$ & $(37.6)$ & $(50.5)$ \\
S.E. $($ si.) & 1.993 & 0.559 & 0.288 & 0.424 & 1.769 & 0.680 & 0.699 \\
LSD $(5 \%)$ & & & & & & & \\
for means & 4.4 & 1.7 & 1.779 & 2.6 & 10.9 & 4.195 & 4.3 \\
\hline \hline
\end{tabular}

si = Significance level of specific combining effects. 
and 1000 kernel weight. The parents Goen and S-46 for KNS and P-311 and SB - 333 for 1000 kernel weight and grain yield/spike showed positive GCA values. So far, GCA effects of lines are concerned (Table 3), Khirman displayed maximum GCA effect for spike length (0.08) and seeds/spike (0.67), while Mehran registered highest GCA effects for plant height (3.05), number of tillers/ plant (1.00), spikelets/spike (1.92) and seed index (3.42) and Kiran for seeds/spike (0.67) and yield/plant (1.86). However, among the testers, TD-1 manifested highest GCA effects for number of tillers/plant (2.96), spikelets/ spike (0.25), seed index (0.61) and yield/plant (2.22) whereas, Marvi displayed maximum positive GCA effects for plant height (2.88), spike length (0.37) and seeds/spikes (6.41). The GCA effects of lines and testers, therefore suggested that parents Mehran and Khirman among the female lines and TD- 1 and Marvi among the testers may be preferred for hybridization and selection of desirable plants from segregating population so as to improve majority of the characters. In consonance to present findings, Esmail (2007) also found three wheat varieties, Jup/Biy, Giza164 and Sids 4, those exhibited large GCA effects for number of spikes/ plant. The tester cultivar Giza 168 was at the top of GCA effects for yield and its components. Ribadia et al. (2007) from line $\times$ tester analysis noted that female line Flamingo's' was a good general combiner for as many as six yield characters while CPAN-6153 was good general combiner for main spike length. While among the males, H-6178 (5) 6-4-5 exerted significant positive GCA effects for length of main spike, spikelets/ spike and grain yield/plant, yet JD-98-16 and HI-8498 were good general combiners for plant height.

The results for specific combining ability (SCA) effects (Table 2) indicated that maximum positive SCA effect

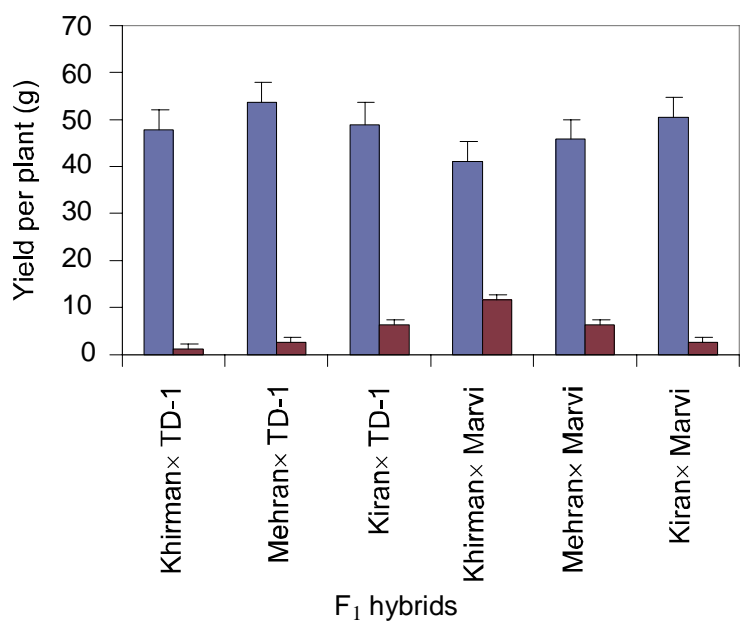

Per se $\mathrm{F}_{1}$ hybrid performance $\square$ SCA effects

Fig. 1. Per se $\mathrm{F}_{1}$ hybrid performance and SCA effects for yield/plant (g).

of 0.51 was displayed by the hybrid Mehran $\times$ TD- 1 for spike length, whereas, Kiran $\times$ TD-1 for plant height (9.50), seeds/spike (10.17) and Khirman $\times$ Marvi for tillers/plant (9.84), spikelets/spike (4.00), seed index (6.11) and yield/plant (11.37). These results suggested that various hybrids may be considered for hybrid crop development. Present findings are in agreement with those of Inamullah et al. (2006) who reported high SCA effects for tillers/plant, plant height, spike length, grains/ spike, 1000-grain weight and yield/plant in hybrids FS $\times$ Dera, Tat $\times$ SQ, Tat $\times$ SARC, Tat $\times$ SQ, Tkb $\times$ SARC and $\mathrm{SQ} \times$ Dera, respectively.

\section{Conclusion}

It can be concluded from the present research that the hybrids differed significantly for their mean performance regarding all the traits studied except spike length. The

Table 3. General combining ability estimates of line and testers for various characters in spring wheat $F_{1}$ hybrids

\begin{tabular}{|c|c|c|c|c|c|c|c|}
\hline Parents & Plant height & Tillers/plant & Spike length & Spikelet/spike & Seeds/spike & Seed index & Yield/plant \\
\hline \multicolumn{8}{|c|}{ Lines/Female parents: } \\
\hline Khirman & -0.20 & -0.75 & 0.08 & -0.83 & 0.67 & -1.71 & -3.55 \\
\hline Mehran & 3.05 & 1.00 & -0.40 & 1.92 & -1.33 & 3.42 & 1.70 \\
\hline Kiran & -2.82 & -0.24 & -0.33 & -1.08 & 0.67 & -1.71 & 1.86 \\
\hline S.E. (gi.) & 0.998 & 0.395 & 0.204 & 0.300 & 1.251 & 0.481 & 0.494 \\
\hline \multicolumn{8}{|c|}{ Testers/Male parents: } \\
\hline TD-1 & -2.86 & 2.96 & -0.37 & 0.25 & -6.42 & 0.61 & 2.22 \\
\hline Marvi & 2.88 & -2.95 & 0.37 & -0.25 & 6.41 & -0.61 & -2.21 \\
\hline S.E. (gi.) & 0.815 & 0.322 & 0.166 & 0.245 & 1.021 & 0.392 & 0.404 \\
\hline
\end{tabular}

gi = Significance level of general combining effect. 
GCA and SCA variances were significant for all the traits with few exceptions, yet the magnitude of variances due to GCA for both lines and testers were generally higher than SCA (lines $\times$ tester interaction) indicating preponderance of additive genes in the control of traits. Among the lines, Mehran and Khirman and from the testers, TD-1 and Marvi were the best general combiners for all the traits studied thus can reliably be used in hybridization programmes so as to select the desirable plants from segregating populations. The specific combining ability effects indicated that for hybrid crop development, crosses Mehran $\times$ TD-1 for spike length; Kiran $\times$ TD-1 for plant height and seeds/spike and Khirman $\times$ Marvi for number of tillers/plant, spikelets/ spike, seed index and yield/plant may be the hybrid of choice to exploit heterosis for higher productivity.

\section{References}

Baloch, M.J., Bhutto, H.U. 2003. Design-II analysis for estimating general and specific combining ability effects of cotton leaf curl virus resistant inbred parents. Zagazig Journal of Agricultural Research, 30: 635-649.

Dhadhal, B.A., Dobariya, K.L. 2006. Gene action and combining ability analysis over environments for grain yield and its components in bread wheat (Triticum aestivum L.). National Journal of Plant Improvement, 8: 172-173.

Esmail, R.M. 2007. Detection of genetic components through triple test cross and line $\times$ tester analysis in bread wheat. World Journal of Agricultural Science, 3: 184-190.

Fida, H., Ashraf, M., Mehdi, S.S., Malik, T.A. 2004. Estimation of heterosis for grain yield and its related traits in wheat under leaf rust conditions. Journal of Biological Science, 4: 637-644.

Gomez, K.A., Gomez, A.A. 1984. Statistical Procedures for Agriculture Research. $2^{\text {nd }}$ edition, John Wiley and Sons Inc., New York, USA.

Hamada, A.A., El-Seidy, E.H., Hendawy, H.I. 2002. Breeding measurements for heading date, yield and yield components in wheat using line $\times$ tester analysis. Annals of Agricultural Science (Cairo), 47: 587-609.

Inamullah, Mohammad, F. S., Hassan G., Ali, S. 2006. Combining ability analysis for important traits in bread wheat. Sarhad Journal of Agriculture, 22: 45-50.

Kempthorne, O. 1957. An Introduction to Genetic Statistics, pp. 468-473, John Wiley and Sons, Inc. New York, USA,

Nazan, D. 2008. Genetic analysis of grain yield per spike and some agronomic traits in diallel crosses of bread wheat (Triticum aestivum L.). Turk Journal of Agriculture and Forestry, 32: 249-258.

PARC 2006. Wheat Grown in Pakistan, pp. 1-7, Pakistan Agriculture Research Council (PARC), Islamabad, Pakistan.

Patwary, A.K., Ghani, M.U., Rehman, M.M. 1986. Heterosis in wheat. Indian Journal of Agriculture Science, 56: 382-384.

Rajara, M.P., Maheshwari, R.V. 1996. Combining ability in wheat using line $\times$ tester analysis. Madras Agriculture Journal, 83: 107-110.

Ribadia, K.H., Ponkia, H.P., Dobariya, K.L., Jivani, L.L. 2007. Genetic diversity in macaroni wheat (Triticum durum Desf.). Journal of Maharashtra Agriculture Universities, 32: 32-34.

Sedeque, Z.A., Bhowmik, Ali, M.S. 1991. Estimates of heterosis in wheat (Triticum aestivum L). Annals of Bangladesh Agriculture, 1: 75-79.

Singh, R.K., Choudhry, B.D. 1979. Biometrical Methods in Quantitative Genetic Analysis, pp. 191-200, Haryana Agricultural University, Hisar, India.

Singh, S. K., Singh, R. M. 2003. Gene action and combining ability in relation to development of hybrids in wheat. Annals of Agricultural Research, 24: 249-255.

Sprague, F.F., Tatum, L.A. 1942. General versus specific combining ability in single crosses of corn. Journal of American Society of Agronomy, 34: 932-952.

Vanpariya, L.G., Chovatia, V. P., Mehta, D.R. 2006. Heterosis for grain yield and its attributes in bread wheat (Triticum aestivum L.). National Journal of Plant Improvement, 8: 100-102. 